\title{
What are you looking at?
}

\section{Editors:}

Jaime Almansa Sánchez \& Elena Papagiannopoulou

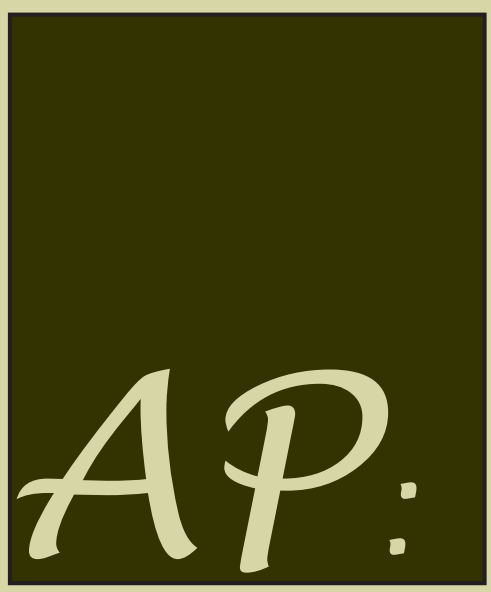

www.arqueologiapublica.es

Ontine Journat in Public Archaeotogy 


\section{What are you looking at?}

\section{Editors:}

Jaime Almansa Sánchez and Elena Papagiannopoulou

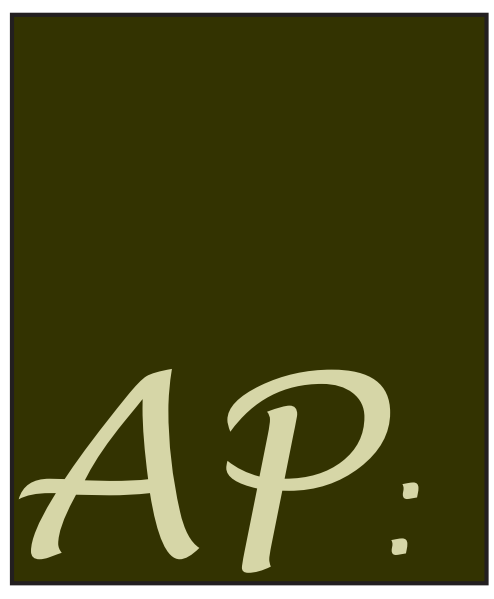

www.arqueologiapublica.es

Ontine Journat in Public Archaeology

AP: Online Journal in Public Archaeology is edited by JAS Arqueología S.L.U. 


\section{INDEX}

Editorial

Jaime Almansa Sánchez and Elena Papagiannopoulou

Forum:

The looting of archaeological heritage (Part II)

Sabita Nadesan, Ivana Carina Jofré Luna \& Sam Hardy

Forum:

Archaeology as a tool for peacemaking

Adi Keinan-Schoonbaert, Ghattas J. Sayej \& Laia Colomer Solsona

Roșia Montană: When heritage meets social activism, politics and community identity

Alexandra Ion

Using Facebook to build a community in the Conjunto Arqueológico de Carmona (Seville, Spain)

Ignacio Rodríguez Temiño \& Daniel González Acuña

In Search of Atlantis:

Underwater Tourism between Myth and Reality

Marxiano Melotti

The past is a horny country

Porn movies and the image of archaeology

Jaime Almansa Sánchez

Points of You

The forum that could not wait for a year to happen \#OccupyArchaeology

Yannis Hamilakis, with a response by Francesco Iaconno

Review

Cultures of Commodity Branding

David Andrés Castillo 
Cultural Heritage in the Crosshairs

Ignacio Rodríguez Temiño

\section{Review}

US Cultural Diplomacy and Archaeology

Ignacio Rodríguez Temiño

Review

Archaeological intervention on historical necropolises

Rafael Greenberg

Review

Arqueológicas. Hacia una Arqueología Aplicada

Xurxo Ayán Vila

\section{Review}

Breaking New Ground

Doug Rocks-MacQueen

\section{Review}

Cultural Heritage and the Challenge of Sustainability

Jaime Almansa Sánchez

\section{Review}

Archaeology in Society and Daily Live

Dawid Kobiałka 


\title{
POINTS OF YOU
}

\section{The forum that could not wait for a year to happen}

\author{
\#OccupyArchaeology
}

Yannis HAMILAKIS

Friends asked me to elaborate on my suggestion for an Occupy movement, not only for art museums and galleries but also archaeological museums, archaeological sites/projects and other culture/heritage institutions that rely on cheap, un-insured, nonunionised labour, or on sponsorship from corrupt corporations.

We in archaeology, art and heritage domains have been for far too long, oblivious, tolerant, if not complicit to a regime of work and political economy which is not sustainable; they tell us about expansion, new markets, new wings for our museums, new museums elsewhere, mega-projects with hundreds of specialists which are going to last for a quarter of a century, and we think: great! Lots of jobs for us and others, more heritage, more culture, more archaeology, that's good all round, right?

Well, no it's not right: who is building that museum, heritage center or your university branch in the Gulf country ruled by a dictatorship? What are their conditions of work and pay, and how many have been killed in workplace accidents, and why? And once that museum or university branch has been built, how can they establish a culture of critique and open dialogue, how can they challenge power and authority, in a context where even the most basic rights of free expression are denied?

Why is beneficial for archaeology and for society to stage megafield projects relying on the funding by corporations such as Shell, with its own dismal record of environmental destruction, and human rights abuse? And how much potential archaeological knowledge has been lost elsewhere (due to oil drilling, and the destruction of habitats), for the archaeological knowledge gained in one specific site?

Why is it great for art and archaeology to stage blockbuster exhibitions at the British Museum or the Tate (and I say this as a 
member), sponsored by BP and other similar companies, with their logos prominently exhibited everywhere? Why are we allowing archaeological and art objects to act as participants in this gigantic theatre of green-washing and complicity?

Where are the new creative, life-transforming and challenging ideas going to come from, if we dance to the tune of our sponsors, and design our research questions, our discussion frames and our rhetoric according to their profile and philosophy?

How many more volumes do we need on "religion" in the Neareastern Neolithic, all funded by the Templeton Foundation?

These are extra-ordinary times. They demand extra-ordinary actions. Hence my suggestion. Occupy Museums in the US is already making a difference. Occupy in archaeological and art museums, galleries and archaeological projects is the next step.

Francesco IACONO

The recent experiment brought about by activists at the Guggenheim Museum represents an interesting attempt and a model for future forms of activism within cultural institutions.

The action/boycott was aimed at making visitors aware of the new expansion plans fostered by the Guggenheim which included the realisation of a new museum in Abu Dhabi that, according to Hyperallergic activists, will be constructed through the use of infamous debt peonage agreements.

The initiative is beyond any doubt laudable; an excellent starting point which can be fruitfully repeated in other Museums and/or cultural institutions. Yet, at the same time, while effective for very specific aims (Guggenheim direction felt immediately the need to respond to protests and clarify the position of the institution), this kind of action falls short of addressing some basic issues that cultural workers really need to start to tackle. In my view the main point is, to put it bluntly, the amount of resources that are allocated to culture. As long as within national budgets of countries public expenditure for culture continues to stay at the current level (e.g. in European countries $0.55 \%$ is the current median value attested) infiltration of 'corporate logic', so to speak, will ineluctably (but not 
without responsibility) drive policy of cultural institutions toward the kind of misbehaviour denounced by activists.

This is the real elephant in the room. Can we lobby and together push to have greater public resources for culture within modern 'democratic' states? I believe that as long as we do not address this, problems similar to those addressed by activists will cyclically emerge. With this, of course, I am not stating that we have to cease to work on the specific, but rather that along with commitment on individual issues, we need to start to deal also with the set of conditions from which these problems stem. To this extent, the first step is to create a real class-consciousness among cultural workers. Whether archaeologists on the field, curators, museum workers, gallery assistants and so on, we are all part of a broad cultural sector with many common interests, and above all, we are all too aware that the amount of resources allocated to culture is growing increasingly scarce. Such a class-consciousness, in turn, needs to be able to win a large consensus and hegemonise public opinion in broader international settings as well as, more traditionally, within each state. Cultural workers must start to address policy-making and advocate for greater resources. Or else they will perish and/ or the whole sector will become increasingly the court jester of corporate power.

In short, what we need, I think, is some sort of global campaign aimed at making people aware of how much culture matters in their life and, at the same time, a transnational organism able to influence states and supra-national institutions alike about the fundamental need for more resources (a good old-fashioned syndicate?).

\section{*Interested in a forum on this topic in our next volume? Just send us your views.}


Almansa-Sánchez, J. Audiences... A review of the CASPAR session at TAG-on-Sea 2013 (Bournemouth University) - 11 February

Papagiannopoulou, E. Multivocality and Technology: Review of a lecture at the Irish Institute of Hellenic Studies at Athens (IIHSA) - 14 February

Touloupa, S. A 30-year retrospect of the Greek Ministry of Culture educational programmes: an insider's insight - 25 April

Touloupa, S. When Public Archaeology is conflated with Cultural Tourism - 7 July

Ion, A. Some thoughts on the 20th European Association of Archaeologists Conference in Istanbul - 26 September

You can read them at:

http://arqueologiapublica.blogspot.com/ - Reviews 


\section{HOW TO CONTRIBUTE}

AP: Online Journal in Public Archaeology welcomes original contributions that match the aims of the journal and have not been previously published anywhere else, or are not on the way to be published elsewhere. Being online and free can be understood as a sign of quality degradation, but this is not a barrier. It is just a way to adapt from the very first moment to the new panorama in research, where the Internet is the main vehicle for transmission, and more specifically in our field, where the prices of journals are unaffordable for any researcher that is not linked to a research institution. We try to give the widest publicity to the journal, to make it Public.

Having made this clear, the papers can be sent in different ways:

-Mail:

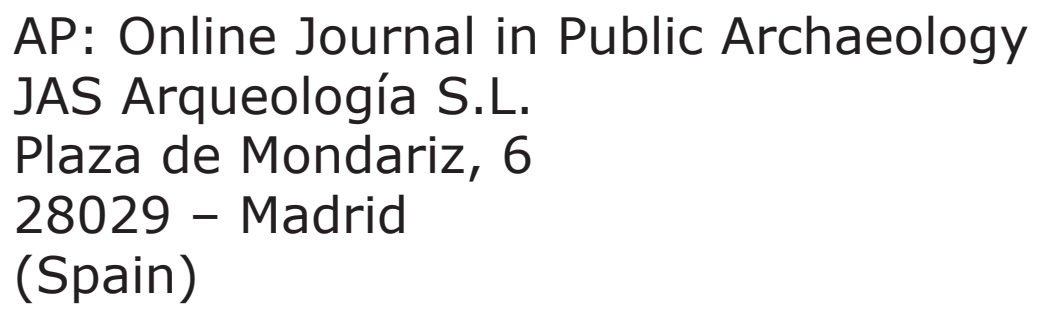

-Email:

jasarqueologia@gmail.com

-Filemail.com:

Filemail.com (www.filemail.com) is a free tool to send large files that exceed the upload limit of a normal email account (Gmail, for example, permits up to $25 \mathrm{Mb}$ ). It is a useful way of sending, for example, large images. In this case, please contact us via email first in case we are not able to get them immediately (the link expires in three days). Of course, any other similar application can be also accepted, like Wetransfer or Dropbox.

\section{STYLE}

Length:

Full articles - We will only accept papers of less than 10.000 words (including notes and references) with a maximum of 10 figures (tables are counted as text). 
Work reports - We will only accept papers of less than 5.000 words (including notes and references) with a maximum of 5 figures (tables are counted as text).

Reviews - We will only accept papers of less than 2.000 words (including notes and references) with 1 figure, that in case of book reviews will be the cover. In other events (conferences, film festivals...), the figure must clearly reflect the event.

Presentation:

To follow the indications of Public Archaeology (www.maney. co.uk/journals/pua), and aiming to standardize the procedures from our side, all material should follow the MHRA Style Guide, which can be freely downloaded from:

http://www.mhra.org.uk/Publications/Books/StyleGuide/index.html

Figures:

The quality of figures should be good enough to be clear in a PDF file. There will not be any weird rule for the submission of the files. Just submit the figures in any readable format (able to be edited in Adobe Photoshop $(\mathbb{B})$. Every camera, software of scanner can make good quality images, so just submit originals. If any figure is subject to copyright it will be essential to attach a written permission from the holder of the rights. To avoid any inconvenience, we encourage the publication of self-owned images. In any case, the author will be responsible for any violation of copyright issues.

Notes and references:

It is preferable to avoid footnotes in the text, just quote or explain in brackets.

For references use Harvard style (Author 2010: 322) followed by a final bibliography. For example: 'according to Author (2010: 123) Public Archaeology can be...' or 'it has been pointed out (Author 2010: 13) that...' etc.

Multiple citations should be in alphabetical order and separated by a semi-colon, (Author et al., 1990; Creator and Author 2003; Producer 1982).

Where an author has several publications from the same year, distinguish them with 'lower-case' letters (Author 2010a, 2010b). Do not use ibid. 
In the final bibliography follow the system below:

Thesis

Castillo Mena, A. 2003. La Gestión del Patrimonio Arqueológico en la Comunidad de Madrid. Unpublished PhD thesis, Universidad Complutense de Madrid.

Journal article

Matsuda, A. 2004. The concept of "the Public" and the aims of Public Archaeology. Papers from the Institute of Archaeology 15, 66-76.

Book

Demoule, J. P. 2007. L'archéologie préventive dans le monde. Apports de l'archéologie preventive a la connaisance du passé. Paris, La Décuverte.

Edited book

Durbin, G. (ed.) 1996. Developing Museum Exhibitions for Livelong Learning. London, GEM.

Section in book

McEwan, C., Silva, M. I. and Hudson, Ch. 2006. Using the past to forge the future: the genesis of the community site museum at Aguablanca, Ecuador. In H. Silverman (ed.), Archaeological site museums in Latin America. Gainesville, University of Florida Press, 187-216.

Internet reference

United Nations 1992, Agenda 21. Retrieved on 29 January 2010 from WWW [http://www.un.org/esa/dsd/agenda21/res_agenda21_00. shtml]

(As it is an online publication, all the quotes referring to an Internet address should be active links).

In the case of any other kind of reference not mentioned here, please contact the editor. 
Once the article has been received:

The process for the acceptance of papers will be easy and fast. Once the article has reached the editor, the decision will be taken in less than 48 hours. Papers rejected from the editor will not be considered again unless they undertake major changes. Correspondence will not be continued for those papers. If the paper is pre-accepted by the editor, it will be peer-reviewed by two different experts in the common blind process. After that, the author will be given feedback and advice in order to go over the article, which will be corrected again to check if it meets the requirements of the reviewers. Once this process has finished, the article will be edited as it will appear on the journal and returned to the author for a final check (only spelling mistakes or other details, not changes on the text). The commitment of the journal is to be able to complete the whole process in less than two months.

Work reports and reviews will not need to pass the peer-review process, but will be commented by the editor.

We will be publishing one volume per year (first trimester) and although we are willing to receive papers the whole year, full articles for next-year's volume should be sent before October in order to complete the process with time.

If you have any queries, please do not hesitate to contact the editor at: jasarqueologia@gmail.com 


\section{LIST OF DONORS}

We want to thank all the people that is helping to maintain this journal. Especially those that chose to use one of the procedures in the donations page. Every little help is welcome to continue with this project, and we expect to increase this list year by year with your help.

Thank you very much:

Vicky Papagiannopoulou

Giannis Papagiannopoulos

Alipio Sánchez

Ma Ángeles Sánchez

José Ma Almansa

Mayca Rojo

Gaëlle Cerruti

Carlos Tejerizo

Jacob Hilton

Patrice L. Jeppson

Gemma Cardona 


\section{AP: Ontine Journat in Public Archaeology}

\section{Editors:}

Jaime Almansa Sánchez \& Elena Papagiannopoulou

Email: almansasanchez@gmail.com

Assistant editors:

Dominic Walker

Amanda Erickson Harvey

Kaitlyn T. Goss

Reviews editor:

Alexandra Ion

Assistant production editor:

Alejandra Galmés Alba

Edited by:

JAS Arqueología S.L.U.

Website: www.jasarqueologia.es

Email: jasarqueologia@gmail.com

Address: Plaza de Mondariz, 6, 28029 - Madrid (Spain)

--

Cover Image: What are you looking at? (CAC)

Copyright (C) 2014 JAS Arqueología S.L.U. (edition) \& Authors (content)

ISSN: $2171-6315$

AP Journal is a peer-reviewed journal devoted exclusively to Public Archaeology. It is freely distributed online on the Website:

www.arqueologiapublica.es

You can also follow us on:

Blogger:

= http://arqueologiapublica.blogspot.com/

Twitter:

http://twitter.com/APjournal

Facebook:

http://www.facebook.com/APJournal 